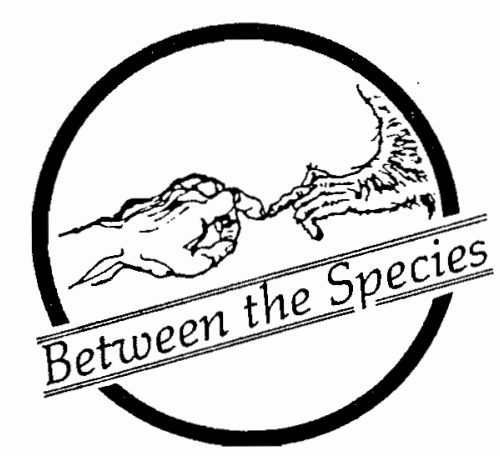

\title{
Up from the Roots
}

\section{George P. Cave}

Trans-Species Unlimited

Williamsport, Pennsylvania

I remember clearly being called a cannibal. I was sitting on a dock in Piraeus with a few friends, eating salami, waiting for the late ship to arrive. We were sailing overnight deck class to the tiny island of Ios, then considered the isle of choice in the Greek Mediterranean for college-educated, would-be drifters like myself. We planned to worship the pagan sun as it rose from the sea over ancient Hellas.

Fifty yards or so from us was a group of hardened, sun-burnt hippies, on their way, as we discovered from eavesdropping on their conversation, to Kathmandu, or wherever the open road of 60's style expatriotism might lead them. They were much more disheveled, impoverished, and in general more interesting and worldly-wise than us.

Being breezy in Piraeus, as it often is, the pungent smell of our salami, bread and cheese supper apparently wafted their way, offending their nostrils. It was a long time before I fully understood their disgust. Today, I too am sickened by the stench of dead flesh. But back then their reaction struck me as cant, a cultish pose adopted by crusaders for eccentric causes. With academic precision, I reflected that the muttered snide remarks about the "group of cannibals over there" were semantically incorrect, an abuse of language, no matter how much tolerance one might have for unconventional dietary habits. After all, we were eating "pork," not people.
Today, militant and abrasive vegetarian and animal rights advocates are more apt to castigate meat-eaters as murderers than as cannibals. Most of them, of course, are not murderers in the strict legal sense, for our legal system has yet to recognize that it is possible to murder non-human animals. Nor do most of them murder their meal themselves. They are simply accomplices to murder - they put out a contract on farm animals through their consumer choices. But in doing so, they are arguably even more guilty than those hunters who consume the victims of the hunt, for they condone not only killing, but also the horrendous suffering of their dinners in today's intensive-confinement factory farms.

But if branding meat-eaters as murderers is linguistically and logically permissible in view of the indispensable role they play in bringing about these animals' untimely deaths, does not the charge of cannibalism also contain an essential element of truth, revealed through hyperbole? We animal rights advocates believe that species barriers are in most

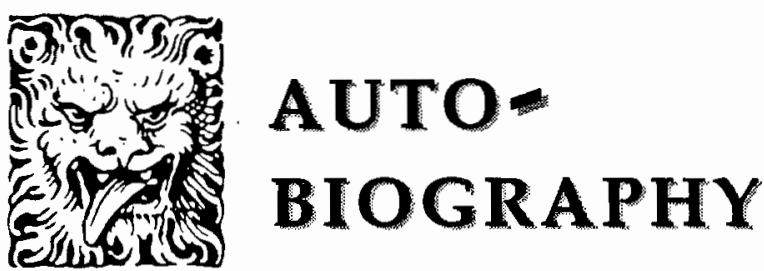


cases artificial constructs, deliberately erected by animal exploiters to justify their use and abuse of the fellow creatures with whom we share this ravaged planet. We are different from them to be sure they have their own ways of behaving, communicating, and being in the world. But we all feel pain, we all suffer, we are all animals.

Racism, sexism, nationalism, and speciesism all depend upon seeing others as essentially other, i.e., not merely as different but as alien, as a threat to the autonomy of our own self-centered competitive existence. What horrifies us about cannibalism is that it is violence practiced against one's own kind. But with the growth of the animal rights movement, we are increasingly learning to see not only other humans but also other animals as our oun kind. And the more we view them as part of an extended earthly family, the more their murder for meat resembles cannibalism.

None of this went through my mind on the dock at Piraeus that summer evening eighteen years ago of course. I dismissed the charges easily enough, albeit with a trace of bitterness, since we callow college kids admired and envied our bedraggled counterparts' resolve to reach the mystic East. Their contempt for our well-entrenched eating habits set them yet further apart from us.

The Piraeus dock incident was the first time I can recall the issue of meat-eating arising in my life. I had grown up as a meat-every-meal man with plentiful doses of animal products thrown in besides. I relished sopping up the roast beef juices with gobs of bread and balked at almost nothing when it came to the consumption of body parts. Pig knuckles, cow tongues, lamb brains, and other assorted meat dishes, which now strike me as grotesque, were all fair fare in those days. I was not a child intuitively horrified by such practices as many children seem to be until their instinctive recoil is stymied by belligerent parents. Yet I do not believe that I was significantly more obtuse or insensitive to animals than most other children. I never harmed an animal in any way to the best of my recollection and never joined those few peers of mine who took up hunting (suburban Washington, D.C. spawned few fledgling hunters).

The truth is, I never gave much thought to other animals at all, and blithely accepted the fact that in the course of things animals had to die to feed us. Had I considered the matter, I suspect I would have acknowledged that slaughterhouses were not the most pleasant places to spend one's time, but neither were battlefields, scenes of natural disaster, morgues and other sites of death and destruction, all of which appeared to me equally part of the natural order.

Certainly I would have supported the elimination of "unnecessary" cruelty in slaughterhouse operations (believing then that animals can be slaughtered "humanely"), but the principal issue - whether animals ought to be in there at all - never arose until years later when I first read the writings of certain philosophers who explicitly asked the question in the context of ethical discussion of animals' rights.

Throughout this long carnivorous period, I was, however, at least morally consistent. To regard the eating of animals as cannibalism or murder was one thing. But to devour some with gusto while shrinking from eating others with horror - that seemed to me the very height of hypocrisy. I remember being half-amused, half-disdainful of the dismay expressed by American exchange students in Aix-En-Provence, France, upon discovering that the strange new entree frequently served in the university cafeterias was chopped horse. In Asia, of course, it might well have been chopped dog. That ambivalence seemed to me symptomatic of a failure to confront life head on, and I wanted no part of such squeamishness. One either accepted the full challenge of being a carnivore or went the way of the Piraeus hippies.

Part of the explanation, no doubt, for the lack of ambivalence on my part was the fact that as a child I had never been excessively fond of animals. I had never had any stirring encounters with tadpoles or woodchucks, nor did puppies and kittens melt my heart. I remember feeling early on that what is now termed the "companion animal bond" was commonly a distasteful relation of domination and servility, and that the irritating, yapping miniature dogs of suburbia were a sorry replica of their noble wolf ancestors. For cats I had a good deal more respect since they seemed to go their own way with a certain aloofness from humans, and could not easily be trained to "obey" or perform tricks. But there were no horses, rabbits or other favored pets in my childhood who might later show up in a different culture on a dinner plate to distress me.

I still believe that preferential concern for a few favored species is seldom the first leg of a journey toward animal liberation, but rather a fundamentally different path leading elsewhere. Liberating animals to me means setting them free to be what they are in 
their own time and place, not molding them into human companions or surrogate children. What is adimirable and refreshing in non-human animals in their native state is precisely the fact that they have no need of human beings. We humans, however, in our monstrous arrogance (or insecurity) have succeeded in creating whole new races of dependent beings, which have no natural niche in the ecosystem and which are by and large incapable of surviving on their own. Whether it is a panting St. Bernard in a stuffy Manhattan studio apartment or a jewel-bedecked ferret in a Beverly Hills suite, our "love of animals" has not led us, as a culture, to an ethic of respect for the other creatures of the earth. Instead millions of these pathetic, deformed, and homeless creatures are exterminated each year in the nation's "shelters," which serve as the dumping ground for the unwanted. Meanwhile the favored few who do find homes are pampered with the flesh of the slain pigs, cows and chickens whom we torture on our factory farms. The pet food industry is big business, and every pet we create is responsible, through us, for the deaths of dozens of farm animals in his or her lifetime.

Such moral paradoxes are inevitable so long as we remain wed to empathy as the pathway to justice. Like other arbitrary and capricious sources of motivation, empathy, sympathy, or love of animals (call it what you will) is intrinsically discriminatory. It manifests itself in the desire to save small animals rather than big ones, young animals rather than old ones, cute animals rather than ugly ones, friendly animals rather than nasty ones, etc. etc.

I always knew that if I stopped eating animals it would be because I was convinced that it was urong, not because I had had a pet horse or rabbit as a child. But how one comes to the realization that it is wrong can, and often does, involve contact with an individual animal. Such was the case with me. Not too long after I started reading Singer, Salt, and other animal rights philosophers, I had a quite mundane but telling experience. It was the offer of a wild rabbit for dinner. The animal had just been shot by a hunter neighbor. He was about to go to the basement of the apartment building where we lived to skin and "gut" the creature. I tagged along, anxious to measure the impact of the grisly deed upon my already tottering carnivorous habits. What struck me as I watched the operation through was the frozen fear in the glassy eyes of the dead rabbit. There had been life and the will to live, here was death and the end of all willing. And here I was, chatting amiably with the perpetrator. I grew increasingly queasy. It was better with the skin off and the eyes gone. It looked more like the packaged flesh I was accustomed to. But the eyes continued to haunt me as I sat down that evening to a meal of wild rabbit meat, and I managed to wolf down only half a portion before I excused myself hastily, went into the bathroom, and threw up.

In the days following, I developed a newfound passion for omelettes and peanut butter and jelly, while I mulled over the peculiar incident. An irrational response, clearly. Hadn't I eaten meat for years? What was my stomach trying to tell me? Maybe it was just the "gamey" taste that hunters always talk about. One thing was clear to me: if I couldn't swallow the reality of freshly killed "game" I had no business continuing to eat plastic packaged flesh. But I was more embarrassed than anything else by my stomach's revolt. So I went back again to the philosophical texts, remembering the rabbit's frightened eyes. I felt no personal affection for the rabbit, not a whit of sentimentality - lean, wild rabbits, after all, are not the cute domestic Easter bunnies that win the hearts of children. What I did feel, however, was an incipient sense of sorrow and remorse, an uneasy, dawning realization of my own insufferable arrogance, in assuming, for so many years, that I had the right to kill a clearly innocent creature for no good reason. For even then I knew that vegetarians somehow got by if need be, on beans.

Peter Singer's account in Animal Liberation of the horrendous ways in which farm animals are raised outraged me - any civilized person knows gross injustice when he sees it - but the central issue then, as now, which Singer's book did not address, was this: "Is it or is it not urong to kill?" Feeble excuses quickly fell away, additional supporting facts - ecological destruction, world hunger, health hazards - buttressed a growing conviction. As previously, I had no doubt that it was in principle absurd to maintain that it was acceptable to kill some animals but not others. The only question remaining was whether to desist altogether, or to dismiss my nausea as a groundless emotional reaction. For three weeks after the rabbit incident I ate no meat. Then I broke down, through weakness or habit. But it wasn't the same as before. Conscience gnawed at my gut and my gorge often rose in the middle of a meal. I a te meat only sporadically, often going meatless for a week or two at a time.

By the end of ten months it was over. I had had enough. By that point my acquaintance with 
philosophical texts on animal rights was well advanced and I had had a horrifying factual glimpse into the holocaust of animal suffering that goes on day after day, minute after minute, throughout this country and the world, behind the closed doors of slaughterhouses, laboratories, and factory farms. I was convinced. Vegetarianism was the first and most obvious consequence of an animal rights position indeed, of even the most basic sense of decency toward one's fellow creatures. For how could one speak of animals' rights and yet deprive them of the most basic right of all - the right to life - without convicting oneself of the most brazen hypocrisy imaginable? So I became a vegetarian, and have remained one happily for almost fifteen years. Short of being lost in the arctic with a hunting rifle and no provisions, I expect to never taste meat again.

My conversion to vegetarianism marked the beginning of my personal commitment to animal rights. It has remained the cornerstone of that commitment to this day, as well as the principal measure of the sincerity of others. For while patience is appropriate when dealing with the general public, which is still gulled by the propaganda of the meat industry, and has little acquaintance with dietary options, there can be no excuse for those who know the facts, profess concern for animals' rights, and yet continue to violate those rights in the most flagrant way possible every time they sit down for a meal. Opponents of animal rights are quick to recognize and point out the contradiction; many large animal welfare organizations apparently are not.

On the other hand, once you decide to stop eating animals, everything else seems to follow. It is a rare vegetarian who hunts, traps, experiments on animals, or wears fur coats. Conversion to vegetarianism invariably ushers in a non-violent lifestyle.

But it does not necessarily usher in activism. Although vegetarianism embodies a personal commitment to animal rights, it does not constitute a political commitment. Vegetarians who did not become vegetarians after they joined the movement tend to be a peaceful, mellow lot, who must usually experience a second conversion before they become activists.

In my own case, it took a while for me to recognize that practicing vegetarianism was not enough. Gradually, I began to see that personal lifestyle choices would never bring down the animal exploitation industries until the animal rights movement gained sufficient power and visibility to persuade large segments of the general public to make those choices. Power does not yield up power willingly, and power is currently in the hands of the exploiters. The two biggest corporate abusers of animals - the vivisection industry and the factory farming industry - are based squarely upon two of the most powerful economic empires in existence today: the modern medical conglomerate and modern Agribusiness. These empires have a big stake in the animal exploitation business and while they can very well tolerate a minority of mellow vegetarians who pursue their own lifestyles without directly threatening their empire, they are not about to sit by idly as militant animal rights activists chop away at their foundations.

What is called for, accordingly, is nothing less than a cultural revolution, which in turn requires a mass movement of gigantic proportions, on the scale of the civil rights and other human liberation movements. When I first became involved in "the movement," I believed that we had the troops necessary to launch that revolution. I banked on the large national animal welfare organizations, which have the lion's share of the financial resources, naively believing that they shared my vision, or could be brought to share my vision, of a holistic political program which would address the interrelated systems of human and animal exploitation, and demand radical change. I though that they could be persuaded to devote their millions of dollars of resources to the attainment of the liberation of animals from human oppression. I assumed that they, like the grass-roots activists I had met, were fundamentally moved by outrage and an impassioned sense of injustice, and that their main concern was to right the grievous wrongs inflicted upon the non-human animals of this world.

I was horrified to discover over the course of time that many of them had investments in corporations which exploit animals in the cruelest ways imaginable; that some had tens of millions of dollars sitting idle while animals continued to suffer and die; that many of their corporate officers had salaries ranging to over $\$ 100,000$ a year and luxurious offices with frivolous amenities that sickened those of us who had to struggle daily for every dollar to implement our campaigns; that almost none of their staff were vegetarians and that they did nothing or next to nothing to promote vegetarianism; that they were almost completely uninterested in, and incapable of mobilizing people for the direct action so essential to the creation of a mass movement, and 
that they did virtually no outreach and recruitment of new people into the movement; that most of their fund-raising mailings were not written by those who signed the urgent appeals, but by fund-raising and promotional companies who pocketed as much as $25 \%$ of the donations intended by contributors to help animals; and that a critical examination of their glossy publications revealed few concrete victories for animals in spite of the millions of dollars of income pouring into the organizations; in short, that most of the large organizations were being run as big businesses rather than as vehicles for social justice.

I knew none of this when I and Dana Stuchell founded Trans-Species Unlimited in 1981. At the time, I was faced with the choice of accepting a fulltime appointment at Penn State University as a writing instructor, seeking a position as a professor in my chosen field of philosophy, or embarking on a new and uncertain path with the burgeoning animal rights movement. In the beginning TSU was only a vehicle for our individual initiative as fledgling activists; we did not envision it becoming an allconsuming passion devouring us 12 hours a day seven days a week. In looking back, I feel that had we not been so bitterly disappointed with the pitiful record of achievement of large national animal welfare organizations, and the shameless treatment accorded us by them, we might well have never continued with the often thankless and frustrating task of trying to create a grass-roots national animal rights organization from scratch. Instead we would have left it to the big groups who already had the power and the money to do it.

But the more familiar we became with the state of the "movement" (for I believe that there is only now beginning to be a movement, in the true sense of the term) the more we felt that essential needs were not being addressed, essential tasks were not getting done, and that TSU or some organization like it was urgently needed and had a unique role to play, if we were ever to create the mass movement we envisioned as the pathway to animal liberation. Many groups were doing many things right but critical gaps remained. In particular, it seemed to us that there was a rift between academic, philosophical concern with animal rights as a moral issue and grass-roots activism. Few of the philosophers writing about animal rights were in the streets implementing their conclusions through direct action, while all too often grass-roots activists seemed incapable of giving a coherent account of the philosophical basis of their action. Concomitantly, there was a failure on the part of activists to apply the conclusions of moral reasoning to concrete strategy decisions or choice of campaigns.

There also seemed to a gap between hard-hitting, militant direct action and professional research and documentation. Organizations producing good information were rarely involved in utilizing that information to implement concrete campaigns, while those involved in militant direct action and protest often were woefully lacking in adequate substantiation of their positions.

Another neglected aspect, it seemed to us, was the internal connections of human and animal abuse. While much lip service was paid to the negative impact of animal abuse on human beings, the factual data to support this contention had not been comprehensively developed in these early days of the movement. Equally important, it was seldom recognized that this impact was not accidental, but that the organized systems of animal abuse were part and parcel of larger systems which also exploit human beings in the most fundamental ways, and that those systems of animal abuse (factory farming, laboratory experimentation, etc.) were in fact modalities through which the systems of human exploitation functioned (i.e., Agribusiness, modern medicine, etc.).

From the beginning of our involvement in the movement, it also struck us as curious that it seemed to be divided between large, national, highly centralized, bureaucratic monoliths and small, grassroots, local groups. While recognizing the tremendous importance of grass-roots groups which maintain a local focus, we also felt that it was imperative to try to create an organization capable of operating on a national, grass-roots level. That has remained our consistent challenge as we have grown from a small, national organization with only one office in central Pennsylvania to a more substantial organization with branch offices in New York City, New Jersey, Philadelphia, and Chicago.

As we gained more insight into the inner workings of the animal welfare and animal rights scene, we also began to recognize that a curious fraud was being perpetrated by many of the so-called national groups. What we came to recognize was that in one very important sense many of these organizations are national in name only. Through the efforts of their fund-raising companies, they acquire a substantial number of donors from every state in the union, but this does not mean that they 
are actively at work throughout the country, in the sense of establishing strong working groups and initiating concrete campaigns and direct actions for animals in different locations on an ongoing basis. The usual pattern, instead, is to hire one or two "staff" people and establish "offices" in key locations. In most cases, no working group is ever established. Experience shows that these staffers' main function is to acquire as much information as possible about what is happening in the movement and occasionally to attend an event, so as to enable the national organizational headquarters to publish news in their quarterly magazine that the organization "supported," "participated in," or, all too often, "spearheaded" the particular effort, which in fact they played little or no role in.

Finally, the movement seemed to suffer from the same syndrome that the political left always seems to suffer from: preaching to the converted, the failure to recognize that fundamental societal structures cannot be altered except through the power of a populist uprising, a mass movement for social justice. In the case of the small, grass-roots groups this took the form of creating tight, cliquish bands and failing to devise appropriate strategies for radicalizing mainstream people and drawing them into the movement. For the large organizations, it took almost the opposite form: diluting the message to ensure maximal fund-raising capability, thereby once again failing to draw the mainstream public into the animal rights arena. There seemed to be a need for a group which did not compromise its message but found the means to make it palatable to the mainstream public through outreach, direct contact, and rigorous substantiation of viewpoints which may appear initially to be extreme or unacceptable.

Such were the concerns that initially impelled us and which continue to form the general framework for Trans-Species Unlimited's endeavors. Starting from nothing, we survived only through dogged perseverance and the faithful support of a handful of loyal supporters and believers in what we were trying to achieve. Throughout this period, what hurt and enraged us the most was seeing ourselves constantly robbed of credit for our efforts by large national animal welfare groups, who cashed in on our modest campaigns at every possible opportunity. For we knew that the significance of such duplicity and theft was far greater than any personal affront to our pride or egos: it translated directly into the loss of income from potential supporters who did not support us because they did not know that we were responsible, income which was always desperately needed to continue our efforts and to expand the range of our activities. We protested these injustices, of course. But we were small and powerless. Who had the resources to bring a lawsuit for theft of services, even if we were willing to squander our loyal supporters' donations to secure justice?

Those years of exploitation and deceit have left a bitter taste in our mouths, and an enduring commitment to never forget the humiliation and rage that such treatment elicited in us, to never turn around and engage in the same unconscionable treatment of other small grass-roots groups once we gained increased power and visibility. For what we have discovered in the course of almost seven years of struggle is that the grass-roots movement is the only hope for animals. And it is a movement still composed predominantly of small, local groups and thousands of dedicated volunteers through the country. Our task as a national grass-roots group which has recently gained some prominence and increased stability is accordingly to nurture that movement in every way possible, to support and promote local activism, to never forget our roots and to remain faithful to grass-roots organizing principles.

But the only option open to us back in 1982 was to grit our teeth and dig in even deeper, work even longer and even harder. As a consequence, at some point during that early period the last vestiges of our personal lives disappeared. In order to leave the days entirely free for TSU work we worked nights at a variety of part-time jobs: driving a rural newspaper route and inputting data at the university library. For the first five years we were volunteers. Not one penny of TSU donations ever went into our pockets to support our activism. Sixteen hour work days merged into sixteen hour work days until the movement became a blur with no end in sight. By the spring of 1986, the work load had become unbearable, and our Board voted to hire Dana and myself at a wage of $\$ 100$ per week. At the time, the decision was a major risk. The extra hours each week that release from our jobs provided quickly filled up and we continued to work $60-80$ hours a week continuously expanding the scope of our campaigns. Gradually, we began to get some recognition for our efforts. We became known as an organization committed to hard-hitting direct action campaigns for animals, and uncompromising dedication to animal rights principles. With our extremely limited resources and primary focus on large scale institutionalized abuses, our concrete victories were few, but we did manage to significantly elevate the 
visibility and media coverage of some major animal rights issues and to score some specific reductions in the level of animal suffering.

The 60 hour work week remains a standard for the TSU staff, which has swollen in the interim to four full-time and several part-time people at our offices in Williamsport, Philadelphia, and New York City. As we continue to expand, we plan to continue hiring workaholics like ourselves at modest wages in key locations throughout the country, where there is maximal opportunity for massive recruitment of new people into the movement and major media coverage of animal issues. We are building a mass movement on the blood and sweat of a few dedicated people because there is no other way to do it. But we are not the only ones. Grass-roots activists throughout the country give as generously of themselves, their time and their resources to bring about the day when the obscene slaughter of our fellow-creatures will be halted. These are the troops of the revolution that is in the making.

With increased staff and increased funding and the tremendous support of grass-roots groups throughout the country, we have begun to be able, during the last year or so, to achieve results never before possible. Our Campaign for a Fur-Free America, with its emphasis upon getting fur out of the mainstream and its militant civil disobedience protests, has escalated the debate on fur to an unprecedented level of prominence. Through extensive networking with other grass-roots groups, we have been able to organize simultaneous direct actions in as many as 45 locations through the country, and to mobilize close to a thousand people in New York City alone. As a result of these efforts direct actions on fur are taking place in hitherto unheard of locations such as lowa, Tennessee, and Utah. The media no longer focuses on the particular cruelties of the leghold trap but has come to recognize that the issue is fur as such, and that the animal rights movement stands for the complete abolition of the animal skin trade.

And this past fall, following an intense three month campaign, we succeeded in shutting down a 13 year laboratory research project involving addiction of cats to barbiturates at one of the most prestigious medical colleges in the country.

These successes show what the grass-roots movement can achieve with even limited resources when it pulls together. For they are successes of the movement - TSU merely led and orchestrated the fight - we could not have done it alone.

As more and more money gets rechannelled into the hands of those who are truly committed to the animal rights movement as a liberation movement, we will see ever more significant victories for animals and ever decreasing suffering and slaughter. We will begin to see the visible signs of a mass movement in the mainstream media - with thousands, then millions of ordinary people marching to a different drummer than the old guard animal welfare bureaucrats, people out in the streets, demanding an end to animal exploitation and slaughter, blockading laboratories, disrupting slaughterhouse operations, hunts, and rodeos. When that day comes, the goal of animal liberation in the truest and fullest sense of the word will begin to become a reality. And then, perhaps, our children or our children's children will be able to get on with their personal lives.

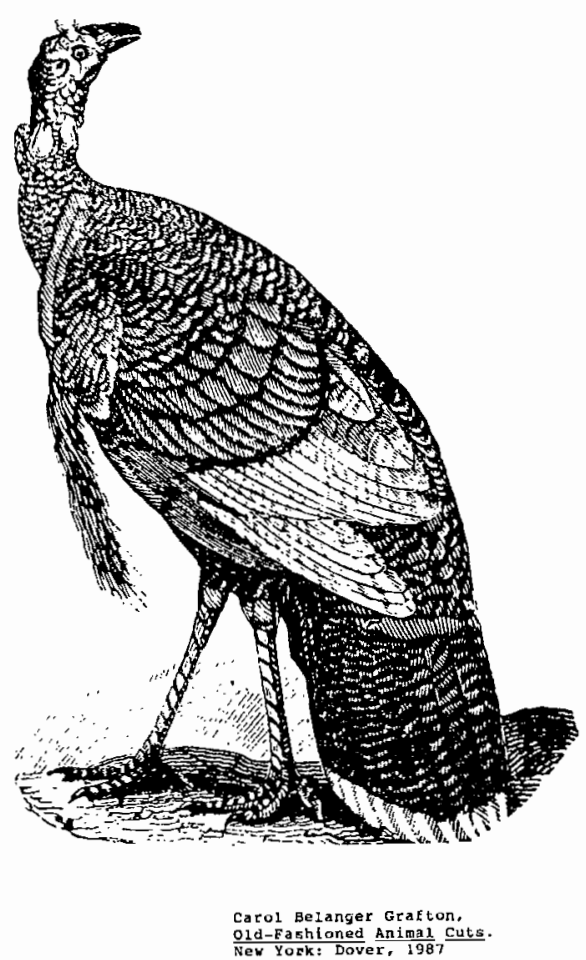

